carrying food. They made many trips with food, into the hole and out, and later passed food to the nestlings from the edge of the hole. They were also observed taking away fecal sacs.

On 17 June two open mouths appeared at the opening and later in the afternoon two heads. In the evening there were nuthatch sounds near the nest tree. Two young birds were seen out of the nest, another was being fed at the hole. It would appear that the latter soon left since the following morning a smaller bird was being fed there by the male adult. The other birds were not seen. The male continued coming with food, being last seen at the nest tree in the morning of 19 June.

After activity ceased at the nest tree, Red-breasted Nuthatch calls were heard regularly in the neighborhood, with occasional sightings. On 30 June four of the birds were observed at a bird bath in the yard.

Through a period of extremely hot and dry weather the pair of Red-breasted Nuthatches proved to be diligent and faithful parents.

\title{
CAROLINA WREN AT LETHBRIDGE, ALBERTA
}

TERESA M. DOLMAN, 37 Carleton Road W., Lethbridge, Alberta. T1K 3X4

At 6:15 a.m. on 21 August 1987, Doug Dolman and the author heard a bird singing very loudly outside the window, and it was not a "regular." The bird was soon located sitting on the porch steps. Before it flew, its wren-like appearance was noted. With binoculars, the bird was observed in the back yard, still singing, but this time giving a different call. It was rummaging around the compost bin and under a large squash plant. From there it flew again, to land in a tree about $8 \mathrm{~m}$ distant and again it sang. Although the sun had barely risen, the sky was clear and viewing conditions good. The bird was larger than a House Wren and had a conspicuous white line over the eye and a solid rufous brown back. When it flew away the field guides were consulted. By appearance, it best fit the description of either the Carolina or the Bewick's wren, and by song, the Carolina Wren. We had neither seen nor heard these two birds before. The neighbourhood was later searched with the hope of hearing the wren without luck.

At $12: 15$ p.m. the wren was again heard. A recording of the Carolina Wren song was then played on a borrowed copy of the National Geographic bird sound records. The wren was located on the property-line fence; it was agitated, scolding constantly and cocking its tail. This scolding was recorded on a portable tape recorder. At a second playback of the Carolina Wren song it flew to the sundeck 
railing, within $2 \mathrm{~m}$ of the open door, then flushed to a rooftop and then to some trees. With binoculars the above-noted features were again seen, plus the underside of the tail, which was finely barred with dark brown, without any white or buff spots. The throat was white and the breast whitish with cinnamon-coloured patches at the shoulders and flanks. There was no streaking on the breast. The beak was long and slightly decurved. The wren flew off shortly, out of recording range, although it continued to sing occasionally. A few hours later I listened to a tape recording of the Bewick's Wren song, and it was entirely different from the calls given by this bird.

At 7:00 a.m. on 22 August the wren was again singing; the "tea- kettle, tea-kettle, tea-kettle" call of the Carolina Wren, as described by Armistead, was recorded. ${ }^{1}$ The National Geographic record was played and once more the wren flew to the sundeck railing. Several times during that day it was heard singing the call described above or giving a loud descending churr note which also was recorded. It returned at least once more to investigate the compost bin and the last time it was heard was about 7:00 p.m.

The wren was identified as a Carolina
Wren on the evidence that:

a) it fit the physical description of that species

b) it was very vocal (Armistead states that songs and calls are given all year ${ }^{1}$ )

c) its songs and calls conformed to that of the Carolina Wren

d) it was attracted by the recorded songs and calls of a Carolina Wren.

The non-migratory range of the Carolina Wren extends in the United States from southeastern Nebraska east to southeastern Massachusetts and south through central and coastal Texas to northeastern Mexico, the Gulf Coast and southern Florida. In Canada it is a permanent resident only in southern Ontario, and rare, casual wanderers have been recorded as far west as southern Manitoba. ${ }^{2}$ Southern Alberta is therefore very much out of its normal range, and one can only guess at the circumstances which brought the bird here. It appeared to be in excellent physical condition and did not appear to be keeping the company of any other birds.

1 ARMISTEAD, H.T. 1983. Carolina Wren. In Audubon Society Master Guide to Birding, J. Farrand, Jr., Ed. Knopf, New York.

${ }^{2}$ GODFREY, W.E. 1986 . The birds of Canada. National Mus. of Natural Sciences, Ottawa. 